\title{
The Impact of Conglomerate farming on the Poor: Empirical Evidence from Brazil Soy Sector
}

\section{Sujin Choi $^{1}$}

Department of Agricultural Economics, Seoul National University, Korea

\section{Hanho Kim}

Research Institute of Agriculture and Life Sciences, Seoul National University, Korea

\begin{abstract}
This paper provides the first econometric results which show that during the period 1976-2013, the conglomerate farming of soybeans aggravated poverty in Brazil. It was found that the impact of soy on poverty in the north of the country, where land consolidation is active, is precisely opposite that of the south, where family farming dominates. The result directly contradicts mainstream views that smallholder farmers' losses would be offset by gains from the trickle-down effect. Based on the findings of this study, a necessity is raised that family farming be supported to help alleviate poverty.
\end{abstract}

Keywords: large-scale farm land; family farming; soy; poverty; Brazil

\section{Introduction}

In Brazil, the world's second largest soy-producing country, soy acreage increased more than 2.5 times during the period 1980-2010, while the areas allotted to all other crops (including sugarcane, coffee, corn, etc.) remained almost the same (Figure 1). Since the 1980 s, $18 \%$ of the Amazon forest in the north; $50 \%$ of the native flora in the cerrado (savannah on the edge of the rainforest), pampas and caatinga (semi-arid scrub forest); and $88 \%$ of the Atlantic forest along the country's coastline have been converted to agriculture in Brazil (Instituto Nacional de Pesquisas Espaciais, 2014; Ferreira et al., 2012; Ribeiro et al., 2009).

\footnotetext{
1 Corresponding author:

Sujin Choi, Department of Agricultural Economics, College of Agriculture and Life Science, Seoul National University, 200-8212, Daehak-Dong, Kwanak-Gu, Seoul, Republic of Korea.

Email: amitie99@snu.ac.kr
} 
In the last two decades, the international market price of soybeans escalated owing to the strong demand from the biodiesel sector as well as the animal feed sector, since using animal protein for the feed was banned due to BSE (bovine spongiform encephalopathy). Accordingly, soy farms advanced further into the Amazon in the north of the country, and this attracted much attention concerning social conflicts between the newcomers and the local poor, since some argue that displaced cattle rangers then migrated into the Amazon rainforest to clear it (Arima et al., 2011; Baletti, 2014; Garrett and Rausch, 2015; Sauer and Leite, 2012; Steward, 2007; Weinhold et al., 2013; see figure 2). ${ }^{1}$ The number of extreme poor in the north, where the Amazon is located, has increased 1.8 times (and more than tripled during the period 1990-2004) from 1990 to 2013, while the figure has decreased in the rest of the country (Figure 3). 
Figure 1. Comparison of acreage growth between soy and other crops.

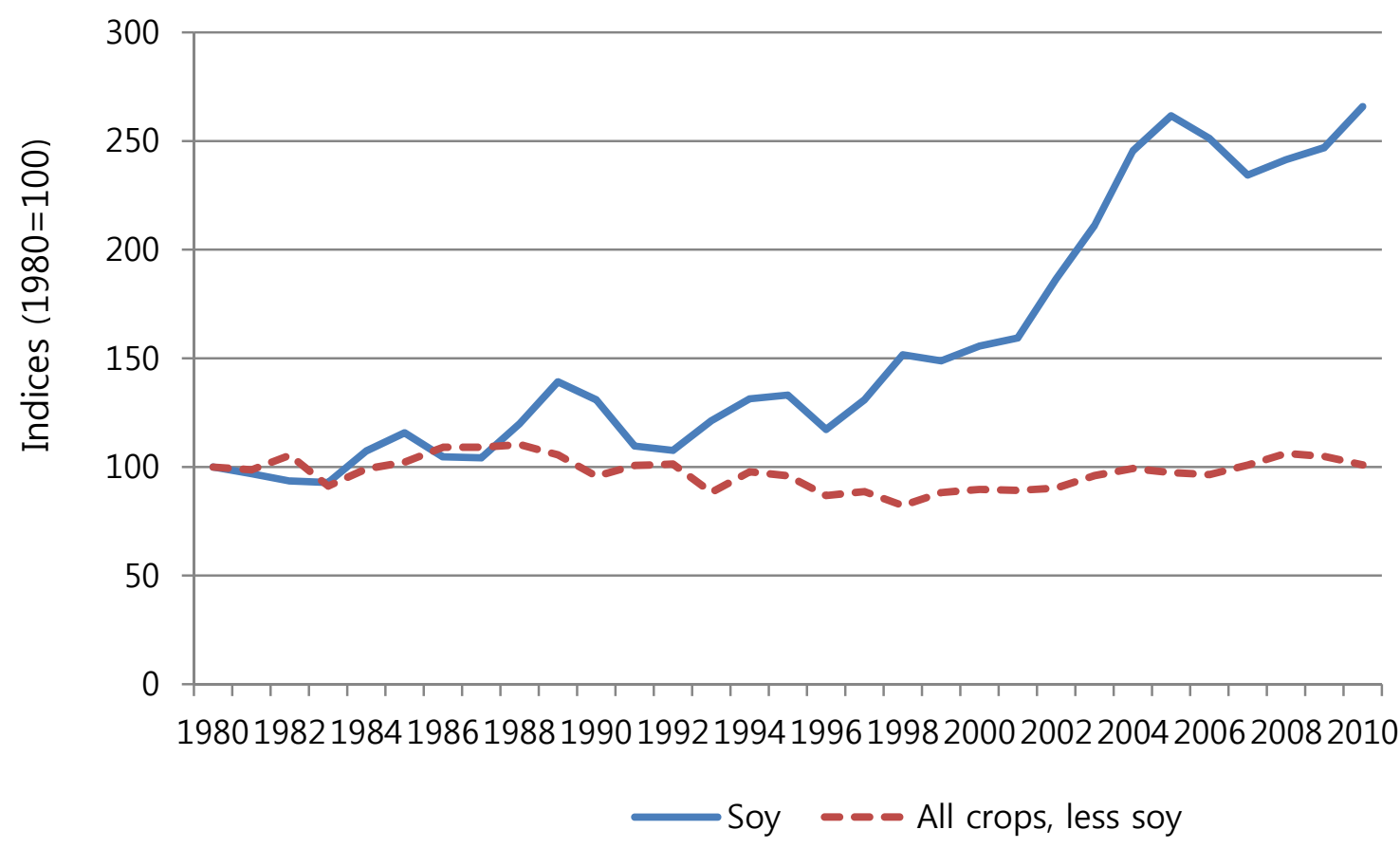

Source: Calculation by author using harvest area data from Instituto de Pesquisa Econômica Aplicada (IPEA) 
Figure 2. Evolution of soybean production 1990-2008.
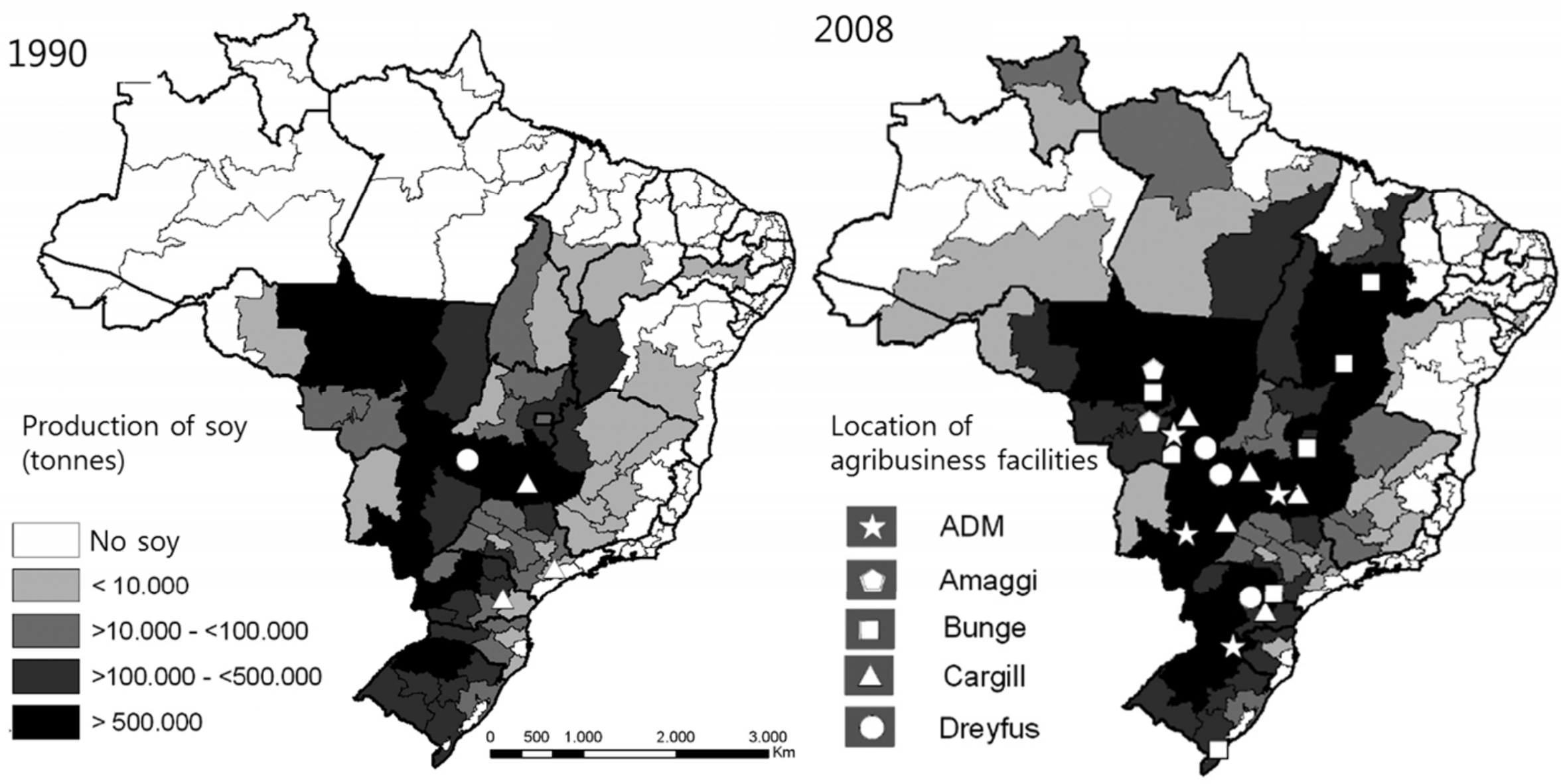

Source: PAM/IBGE, cited in Wesz Jr.(2008), Heredia, Palmeira, and Leite (2010) and Sauer and Pereira Leite (2012) 
Figure 3. Comparison of the number of the poor by region

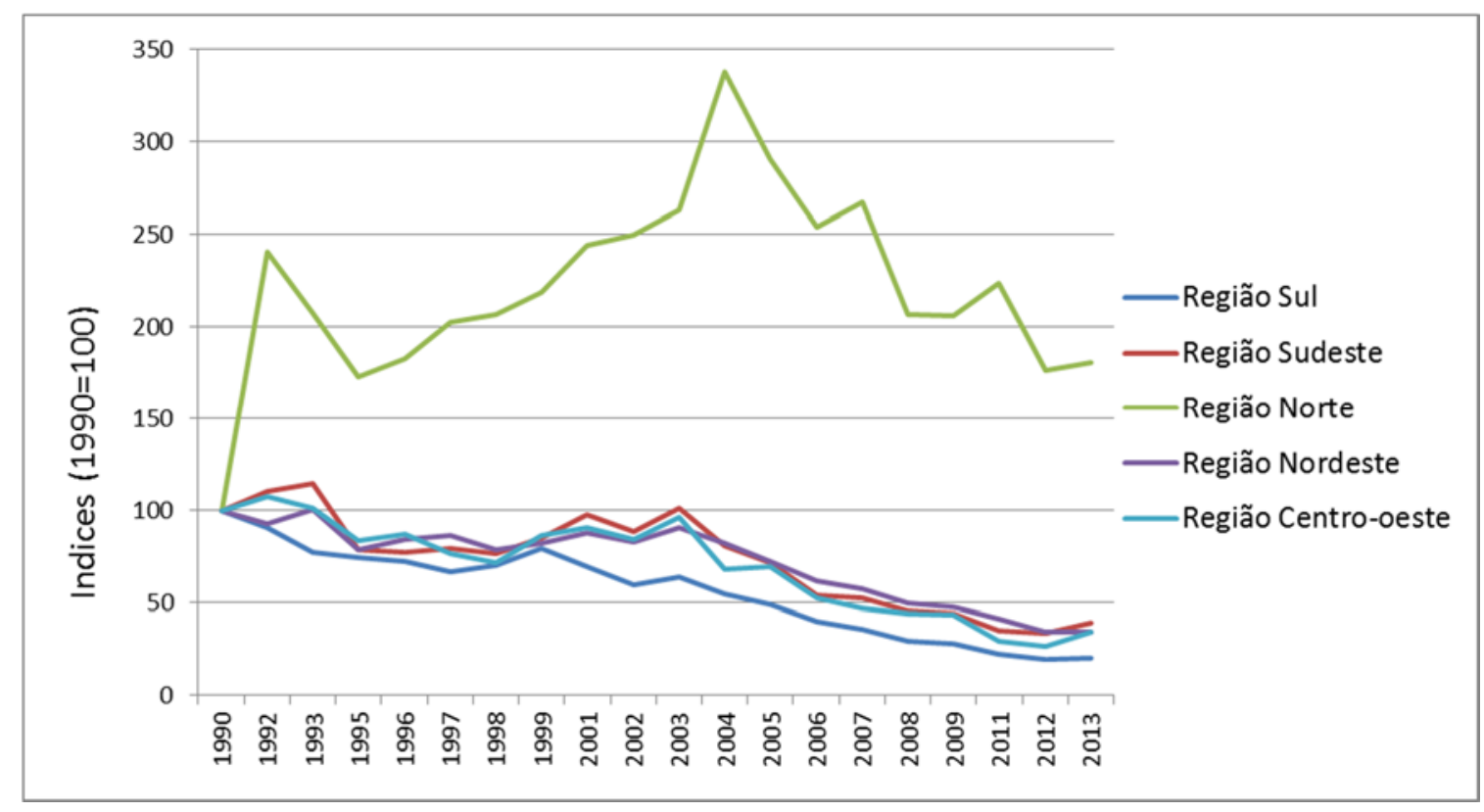

Source: Calculation by author using poverty data from National Survey by Household Sampling (Pesquisa Nacional por Amostra de Domicilios, PNAD) by IBGE

However, there are different styles behind the soy farming in Brazil. The majority of soybeans are produced in the central west and the northeast by large, highly mechanised monoculture plantations oriented towards industrial processing destined for export and this soy sector is dominated by ADM, Bunge, Cargill, Louis Dreyfus, and Amaggi group (Sauer and Leite, 2012; seefigure 2). Nevertheless, there is also a different farming system in the south called 'family farming'. Topography variations and intergenerational land fragmentation limit the farm size, and farmers maximise their profit by labour intensive activities, for example, producing milk and pigs in addition to soybeans (Vennet et al., 2015). There are other features that distinguish family farming from commercial farming. First, the products are either household staples or used for domestic consumption, and second, family farming values resources from nearby forests. 
The purpose of this article is to analyse the causal relationship between soy and poverty and to determine whether soy expansion influences poverty differently in the North (the central west, the northeast and the north) and the South (the south and the southeast) of Brazil, given the different farming systems in these two regions. Though it is critical to find out how and to what extent the soy industry has affected the welfare of the poor, few have empirically studied this issue. Weinhold et al. (2013) noted that in some conditions the expansion of soybeans is negatively associated with poverty but they did not provide explanations for this result. ${ }^{2}$

This study is organized as follows. In Section 2, we explore different soy farming styles, how large-scale investment in farmland aggravates poverty and the growth-inequality-poverty dynamics. In Section 3, we discuss the estimating strategy, including hypotheses, models and data. The estimation is conducted in two steps. First, we investigate the national effect and the northern versus southern regions utilising data at the level of administrative units. Then, we analyse regional effects using data at the municipal level. After that, we present the empirical results - first the national effects, then the comparison of the north versus the south, and finally the regional analysis - in Section 4. Last, we discuss the results in Section 5.

\section{Background}

\section{Regional difference of soy farming in Brazil}

The divide in the geographical distribution of conglomerate farming and family farming dates back to the introduction of the soybean. In the south and the southeast, soy was first introduced before 1962 (i.e., when IBGE started to record). Traditionally, soy was double cropped with wheat in fertile land in the south via family farming in order to feed pigs. Topography variations and intergenerational land fragmentation limited the 
size of farms in the south. However, in the central west, the soybean is relatively more recent. In the relatively flat terrain in the central west, soy farms were introduced in the 1970s after the government agricultural research institute, EMBRAPA (Empresa Brasileira de Pesquisa Agropecuária), modified the soy species from a temperateclimate species to a tropical one as part of a programme to develop remote regions. ${ }^{3}$ Before the expansion of soy farms, this nutrient-poor area, which was mostly pasture, was considered un-arable. In most of the northeast and in the north, soy was first introduced from the late 1970s to the 1990s (Table 1).

Table 1. Soy introduction year and acreage in major soy cultivation region

\begin{tabular}{|c|c|c|c|}
\hline Region & Administrative Units & Soy Introduction year & Soy acreage (ha) \\
\hline & Rondônia & 1985 & 146,144 \\
\hline \multirow[t]{3}{*}{ North } & Pará & 1997 & 119,686 \\
\hline & Tocantins & 1973 & 415,463 \\
\hline & Maranhão & 1978 & 556,178 \\
\hline \multirow[t]{4}{*}{ Northeast } & Piauí & 1978 & 444,856 \\
\hline & Bahia & before 1962 & $1,112,627$ \\
\hline & Mato Grosso & before 1962 & $6,980,690$ \\
\hline & Mato Grosso do Sul & 1973 & $1,812,968$ \\
\hline & Goiás & 1969 & $2,669,894$ \\
\hline & Distrito Federal & 1974 & 55,050 \\
\hline \multirow[t]{3}{*}{ Southeast } & Minas Gerais & before 1962 & $1,028,341$ \\
\hline & São Paulo & before 1962 & 562,647 \\
\hline & Paraná & before 1962 & $4,456,805$ \\
\hline \multirow[t]{2}{*}{ South } & Santa Catarina & before 1962 & 451,449 \\
\hline & Rio Grande do Sul & before 1962 & $4,156,095$ \\
\hline
\end{tabular}

Source: IBGE 
Note: Soy acreage is data of 2012.

Another feature that divides the south and the north are differences in farming methods. In the central west, the northeast and the north, corporate farming-involving large, highly mechanised monoculture plantations oriented towards industrial processing destined for export—is dominant. In contrast, in the south, the farming method is characterised by mixed farming involving soy/wheat, cows, chickens and pigs. Moreover, productivity is maximised via labour-intensive activity, the forest is part of the farm, biodiversity is important to production and the products are used for home or domestic consumption (Vennet et al., 2015). As of 2006, family farming consists of $10 \%$ of total agricultural land and $71 \%$ of total farmers (IBGE, 2006). The ratio of smallscale farmers is $77 \%$ in the south and $44 \%$ in the southeast, while the figure is only $31 \%$ in the central west, $32 \%$ in the north and $8 \%$ in the northeast (Table 2 ). The average farm size is 69 ha in the south and 401 ha in the southeast, but the average farm size in the central west is more than double that of the southeast, and that in the north and the northeast is triple that of the southeast.

Table 2. Family farming, average farm size and soy acreage ratio by region (2006).

\begin{tabular}{|c|c|c|c|c|c|}
\hline \multirow{2}{*}{ Region } & \multicolumn{2}{|c|}{ Family Farming } & \multirow{2}{*}{$\begin{array}{l}\text { Average Farm } \\
\text { size (ha) }\end{array}$} & \multirow{2}{*}{ Land use } & \multirow{2}{*}{$\begin{array}{c}\text { Percent of } \\
\text { acreage (\%) }\end{array}$} \\
\hline & $\begin{array}{l}\text { Percent of } \\
\text { area (\%) }\end{array}$ & $\begin{array}{c}\text { Percent of } \\
\text { farmers }(\%)\end{array}$ & & & \\
\hline & & & & Soy & 1 \\
\hline \multirow[t]{3}{*}{ North } & 2 & 32 & 1,104 & Other crops & 7 \\
\hline & & & & Pastures & 48 \\
\hline & & & & Soy & 2 \\
\hline \multirow[t]{2}{*}{ Northeast } & 0 & 8 & 1,761 & & \\
\hline & & & & Other crops & 20 \\
\hline
\end{tabular}




\begin{tabular}{|c|c|c|c|c|c|}
\hline & & & & Pastures & 40 \\
\hline & & & & Soy & 7 \\
\hline \multirow[t]{3}{*}{ Central west } & 2 & 31 & 840 & Other crops & 12 \\
\hline & & & & Pastures & 56 \\
\hline & & & & Soy & 2 \\
\hline \multirow[t]{3}{*}{ Southeast } & 5 & 44 & 401 & Other crops & 24 \\
\hline & & & & Pastures & 51 \\
\hline & & & & Soy & 17 \\
\hline \multirow[t]{2}{*}{ South } & 26 & 77 & 69 & Other crops & 37 \\
\hline & & & & Pastures & 38 \\
\hline
\end{tabular}

Source: IBGE 2006 and Garrett and Rausch (2015).

Note: Family farming is defined as acreage up to $20-400$ ha that rely on household labour for production, according to Law 11326. Other crops include permanent and annual crops.

\section{The impact of large-scale acquisition of farmland on poverty}

Unlike the small-scale farming in the south, the dominant farming method in Brazil is corporate farming, which expands acreage northwards by the large-scale acquisition of farmland. Whether the large-scale acquisition of farmland by agribusiness benefits the local poor is a tricky question to answer, because there are both negative and positive impacts. Many have pointed out that the soy boom has increased both income and inequality (Garrett and Rausch, 2015; Hecht and Mann, 2008; Lima et al., 2011; Martinelli et al., 2010; Morton et al., 2006; Weinhold et al., 2013). Lima et al. (2011) report that in Sorriso, where soy has expanded rapidly, the average income is 4.6 times higher than that in Guarantã, where cattle rearing dominates, yet there is evidence of social class formation, because plots are consolidated by farmers who have more skills and capital. 
Recent studies argue that local smallholder farmers, landless labourers, pastoralists, forest dwellers, fisher folk, rural women, ethnic minorities and indigenous people have become more vulnerable because of the expansion of agribusiness, since they have lost their means of living and have been deprived of access to water and land. There are four major explanations that describe how large-scale investment in farmland aggravates poverty (Borras and Franco, 2012; Bues et al., 2011; De Schutter 2011; Gudynas, 2008; HLPE, 2011; Lapola et al., 2013; Smaller and Mann, 2009; and Steward, 2007).

- Land title issues

- Commons

- Job opportunities

- Food security

First, much land in developing countries does not have formal paper titles, and there are discrepancies between de jure and de facto rights. For example, during the paving of the Santarém-Cuiaba highway (BR-163) in Brazil, lands occupied by indigenous landholders were designated for soy expansion, and the rural dwellers had to be displaced (Baletti, 2012). When people are displaced due to land investment projects, the law recognises the value of concrete structures such as houses, but territorial rights are seldom compensated. Registering customary rights, however, is costly and difficult for the disadvantaged, and it also leads to land loss for many. Djiré (2007) reported that land registration for farmers in Mali was a long and high-cost process and came with the danger of fake claims. In addition, people who depend on secondary rights of access are disadvantaged from formalising rights, as $\operatorname{HLPE}$ (2011, p.26) pointed out that in most smallholder farming systems, a bundle of rights comes with land rather than an individual freehold title. De Schutter (2011) claimed that the creation of a land rights 
market itself encourages speculation in land, and this can force small farmers to distress sales if they fall in debt after an occasional bad harvest.

Second, the poor rely on common resources, including streams, grazing woodlands and wetlands. They are vital for cultivation, livestock, fishing and firewood for poorer groups such as women, herders, etc., but the commons are often considered 'idle' or 'available', and people who use these resources are easily displaced without compensation. In a case study of Pará, located in the Amazon in Brazil, Steward (2007) discovered that streams, which are main water sources for the poor, had been filled in for the construction of roads for soy machinery and that land that once supported the lives of 50 tenant farmers had been turned into one soy farmer's property. HLPE (2011, p.29) also pointed out gender issues. Since conventional land policies exclude women, the conversion of community woodland into monoculture plantations ends women's access to vital resources for subsistence and diminishes poor women's income.

Third, on-farm job opportunities have decreased since the arrival of investors. Deininger et al. (2010) reported that in Ethiopia, the average number of employment opportunities made by large-scale farmland is $0.005 \mathrm{jobs} / \mathrm{ha}$. In Madagascar, a large farm investment project created just 0.006 jobs/ha in contrast to the previous land use system, which supported about 1.25 households/ha (Evers et al., 2011). Noronha et al. (2006) reported that soybean plantations employ 0.02 persons/year/ha in Brazil, while the figure is 0.1 persons for sugar cane and 0.49 persons for coffee. This situation increases the competition for rural labourers and puts them in a position of surplus labour, which displaces many who are more disadvantaged. Zoomers (2010) also noted that most of the employment opportunities created by the soy/agribusiness industry are created in the non-agricultural sector, but rural dwellers rarely acquire the positions owing to a lack of proper skills, and instead migrants from the south are employed. 
Fourth, the subsistent farmers are net buyers of food, and they are exposed to the danger of higher food prices after commercial farming replaces food crops for domestic use with cash crops for export. Soy is mainly grown for feed, oil or biodiesel and has few direct food uses, and it worsens the availability of food in local areas. This can make the poor more vulnerable to external shocks, such as harsh climate, pests and crop disease, which also leads small farmers to sell their land plots.

Nonetheless, the mainstream view on this matter stresses that local peasants would eventually benefit, because the overall welfare of the population increases thanks to increased foreign exchange earnings, infrastructure and opportunities from the investment (Deininger et al., 2010). It follows the conventional notion of the trickledown effect from economic growth. Baumgartner et al. (2015) argued that overall labour productivity as well as wage levels would increase as a result of investment in capital (i.e. mechanisation of agriculture as well as industrial factories by agribusiness). However, this is based on an implausible assumption of complete flexibility of farmers across jobs, which means that even though there may be loss for the poor in the agricultural sector, it will be compensated for by the benefit for the poor in the nonagricultural sector.

The productivity growth in the agricultural sector in developing countries allegedly reduces rural poverty for the following reasons (Grewal et al. 2012, p.29). First, the rural poor have difficulty in finding jobs in the non-agricultural sector due to their illiteracy or low-level education. Second, there are people who are discriminated against in employment in the non-agricultural sector for being women, ethnic minorities or indigenous people. Third, most of the rural poor depend on their own products and employment in the agricultural sector. Therefore, agricultural development is believed to reduce rural poverty for the very reason that the rural poor have difficulty in getting 
jobs in the non-agricultural sector. Accordingly, agricultural productivity gained by mechanisation and with little job creation in the agricultural sector does not seem to benefit the poor.

\section{Growth-inequality-poverty dynamics}

In the above section, we described how poverty is aggravated by the large-scale acquisition of farmland. The goal of this study is to answer the following question: 'When soy expansion raises the average income at the cost of inequality, what will its subsequent net impact on the poor be?' For the purpose of the empirical analysis, we break down the growth-inequality-poverty dynamics of soybeans into growth-poverty and inequality-poverty effects.

The idea that the impact of growth and inequality on poverty should be measured separately has been explored by Jain \& Tendulkar (1990), Ravallion and Huppi (1991), Datt and Ravallion (1992), Kakwani (1993) and Bourguignon (2003). Figure 3 is shown to help understanding this approach. The two shaded areas to the left of the poverty line (here set at one dollar a day) illustrate (1) the effect of growth on poverty when inequality does not change and (2) the impact of the distribution of income when the mean income does not change. In other words, a change in poverty is due to both a shift of the density curve to the right and a change of the variance for this distribution. It can be inferred that a 'bigger pie' intrinsically reduces the number of poor people, but this gain would shrink as the tails become thicker. Therefore, if the variance gets larger to the point where the gain disappears, the number of poor people may rather increase after that. Hence, we cannot be sure of the net effect of the growth that accompanies inequality unless we quantify it. 
Figure 4. Decomposition of change in poverty into growth and distributional effects.

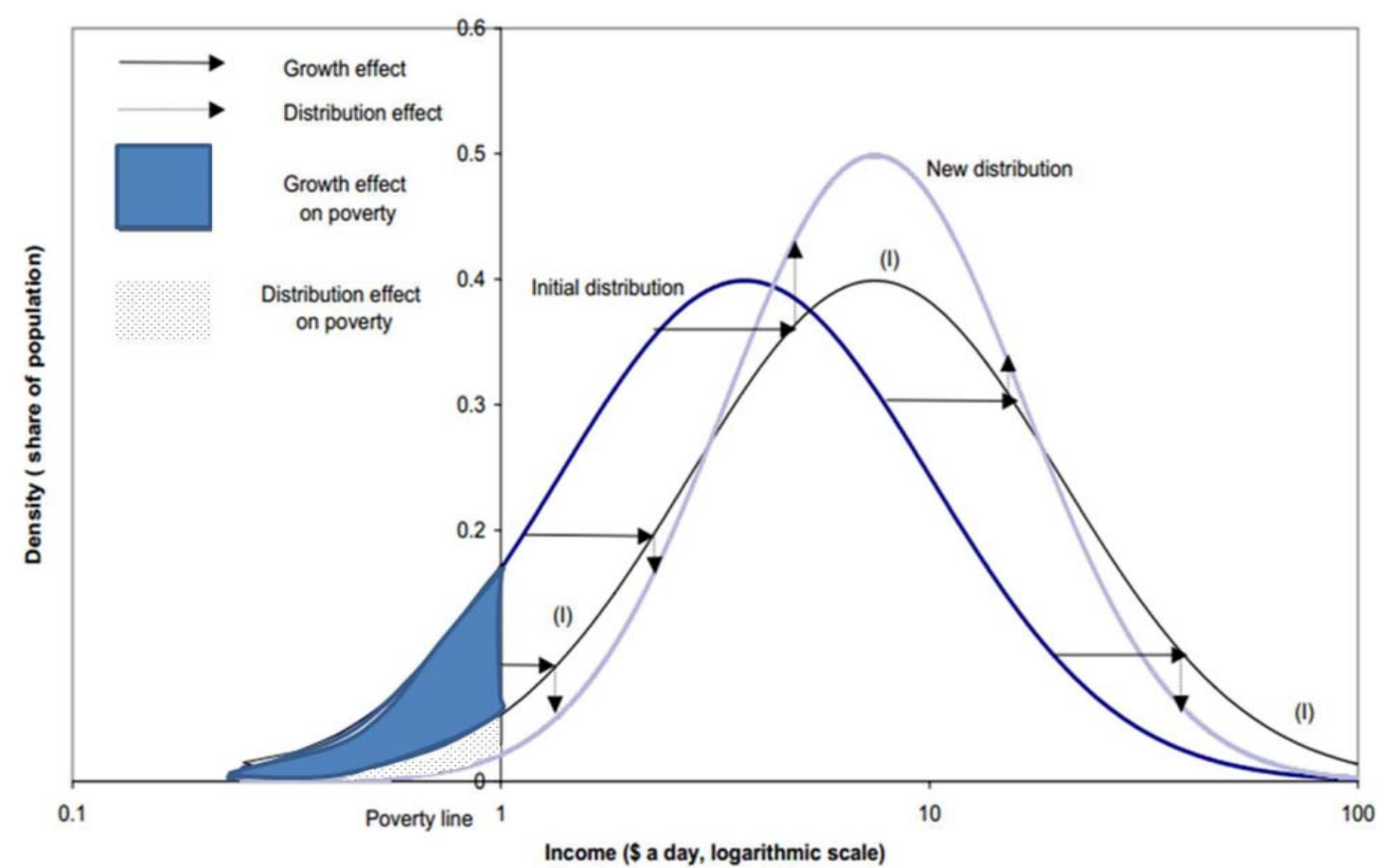

Source: Bourguignon (2003)

Note: The density curve takes a normal distributional form for simplicity.

For measurement of the net impact on the poor, we adopt the model of Kakwani (1993), which is driven from Lorenz curve with an assumption of a fixed absolute poverty line.

$$
\frac{d \theta}{\theta}=\eta_{\theta} \frac{d y}{y}+\varepsilon_{\theta} \frac{d G}{\mathrm{G}}
$$

Where $\theta$ denotes the headcount of the poor and $y$ and $G$ are the mean income and Gini index respectively. $\varepsilon_{\theta}$ is the effect of the change in the Gini index on the poverty while controlling for the growth effect. $\eta_{\theta}$ is the effect of the change in growth on poverty while controlling distributional effect. 


\section{Estimating strategies}

\section{Net impact of growth and inequality owing to soy expansion on the poor}

We translate our research question into three hypotheses with functional forms. It is assumed that there is a feedback between growth and inequality.

Hypothesis 1 describes that the acreage growth, together with soy $(\varphi)$ and other crops (v), leads to average income (y) growth when average income can be expressed as a function of acreage of soy and other crops and Gini index $(G) . v$ is area for all crops less soy. Hypothesis 2 illustrates that increase of soy acreage leads to higher Gini index under the assumption that inequality is a function of acreage of soy and other crops less soy (v) and average income. Then, we would like to find out hypothesis 3, 'what would happen to the number of persons below the poverty line $(\theta)$ when soy farm expands, when poverty is the function of average income and Gini index?'

- Hypothesis 1: $y=f(\varphi, v, G)$

$$
\begin{aligned}
& \frac{d \log y}{d \log \varphi}>0 \\
& \ln y=\alpha \ln v+\beta \ln \varphi+\gamma \ln G i n i
\end{aligned}
$$

- $\quad$ Hypothesis $2: \mathrm{G}=\mathrm{f}(\varphi, v, y)$

$$
\begin{aligned}
& \frac{d \log G}{d \log \varphi}>0 \\
& \ln G \operatorname{in} i=\alpha^{\prime} \ln v+\beta^{\prime} \ln \varphi+\gamma^{\prime} \ln y
\end{aligned}
$$

- Hypothesis 3: $\theta=\mathrm{f}(\mathrm{y}, \mathrm{G})$

$$
\frac{d \log \theta}{\operatorname{dlog} \varphi} \quad ?
$$


As $y=\mathrm{f}(\varphi, v, G)$ and $\mathrm{G}=\mathrm{f}(\varphi, v, y)$, we substitute mean income and Gini index in the model of Kakwani (1) with equation (2) and (3) respectively.

$$
\begin{aligned}
\ln \theta & =\eta_{\theta}(\alpha \ln v+\beta \ln \varphi+\gamma \ln \text { Gini })+\varepsilon_{\theta}\left(\alpha^{\prime} \ln v+\beta^{\prime} \ln \varphi+\gamma^{\prime} \ln y\right) \\
& =\left(\eta_{\theta} \alpha+\varepsilon_{\theta} \alpha^{\prime}\right) \ln v+\left(\eta_{\theta} \beta+\varepsilon_{\theta} \beta^{\prime}\right) \ln \varphi+\left(\eta_{\theta} \gamma+\varepsilon_{\theta} \gamma^{\prime}\right) \ln y
\end{aligned}
$$

In (4), $\eta_{\theta} \beta$ is growth impact on the poor due to soy acreage and $\varepsilon_{\theta} \beta^{\prime}$ is distributional impact on the poor due to soy acreage. We arrange (4) as (5), where $\beta_{\theta \varphi}=\eta_{\theta} \beta+\varepsilon_{\theta} \beta^{\prime}$, which is the net impact of growth and inequality owing to soy acreage expansion on the poor.

$$
\frac{d \theta}{\theta}=\alpha_{\theta v} \frac{d v}{v}+\beta_{\theta \varphi} \frac{d \varphi}{\varphi}+\eta_{\theta y} \frac{d y}{y}+\varepsilon_{\theta G} \frac{d G}{G}
$$

$\beta_{\theta \varphi}$ in (5) is the elasticity of poverty with respect to soy acreage as shown in (6) and this is the parameter we have interest.

$$
\beta_{\theta \varphi}=\frac{d \theta}{d \varphi} \frac{\varphi}{\theta}
$$

\section{Two-way fixed effect and random effect models}

In analysing the impact of the expansion of soy acreage on the poor, one of the challenges is to remove the spurious effects. There are many latent variables that influence income, inequality, and poverty. It is possible for soy expansion to have indirect effects on growth, inequality, and poverty through latent variables such as a lack of socioeconomic institution or each region's endowment of public and private resources, including convertible land. In other words, there are unobservable causes that make once poor regions remain poor. For instance, the northeast remains to be the poorest, and south and southeast regions have less poverty and the gap among regions 
does not tend to get narrowed. We suggest that latent variables be controlled by considering it as time-invariant regional specificity in panel fixed effect model because the impact from them repeats over the observations on the same region. The unobservable time-invariant fixed effect is set as $\delta_{i}$

We also include a time dummy for each year in order to capture the impact of explanatory variables on the dependent variable properly. This study utilizes data from 1976 to 2013 and during the period, there may have been events associated with natural increase or decrease in income, inequality or poverty as time goes by. The time specific effect is denoted as $v_{t}$. (7)-(9) corresponds hypotheses $1-3$.

$$
\begin{aligned}
& \ln y_{i t}=\alpha \ln v_{i t}+\beta \ln \varphi_{i t}+\gamma \operatorname{lnGini} i_{i t}+\delta_{i}+v_{t}+e_{i t} \\
& \ln \operatorname{Gini}_{i t}=\alpha \ln v_{i t}+\beta \ln \varphi_{i t}+\gamma \ln y_{i t}+\delta_{i}+v_{t}+e_{i t} \\
& \ln \theta_{i t}=\alpha \ln v_{i t}+\beta \ln \varphi_{i t}+\gamma \ln y_{i t}+\zeta \operatorname{lnGini} i_{i t}+\delta_{i}+v_{t}+e_{i t}
\end{aligned}
$$

To exclude the impact from regional specificity $\left(\delta_{i}\right)$, which we hypothetically set as the cause of spurious effects, (10)-(12) panel two-way error components fixed effect

models are established for (7)-(9) where $\epsilon_{i t}=\delta_{i}+v_{t}+e_{i t}$.

$$
\begin{aligned}
\ln y_{i t}-\ln \overline{y_{l t}}= & \alpha\left(\ln v_{i t}-\ln \overline{\mathrm{v}_{l t}}\right)+\beta\left(\ln \varphi_{i t}-\ln \overline{\varphi_{l t}}\right)+\gamma\left(\ln G i n i_{i t}-\ln \overline{G \ln l_{l t}}\right)+ \\
& \left(\epsilon_{i t}-\overline{\epsilon_{l t}}\right) \\
\ln G i n i_{i t}-\ln \overline{G \ln l_{l t}} & =\alpha\left(\ln v_{i t}-\ln \overline{\mathrm{v}_{l t}}\right)+\beta\left(\ln \varphi_{i t}-\ln \overline{\varphi_{l t}}\right)+\gamma\left(\ln y_{i t}-\ln \overline{y_{l t}}\right)+ \\
& \left(\epsilon_{i t}-\overline{\epsilon_{l t}}\right)
\end{aligned}
$$




$$
\begin{gathered}
\ln \theta_{i t}-\ln \overline{\theta_{l t}}=\alpha\left(\ln v_{i t}-\ln \overline{\mathrm{v}_{l t}}\right)+\beta\left(\ln \varphi_{i t}-\ln \overline{\varphi_{l t}}\right)+\gamma\left(\ln y_{i t}-\ln \overline{y_{l t}}\right)+ \\
\zeta\left(\operatorname{lnGini}_{i t}-\ln \overline{\operatorname{Gln}}_{i t}\right)+\left(\epsilon_{i t}-\overline{\epsilon_{l t}}\right)
\end{gathered}
$$

However, it is also plausible that some or all of regional specificity $\left(\delta_{i}\right)$ is stochastic due to the impact from government policy, topography, and climates. For instance, some regions may have damage from natural disaster while other regions are not affected and this difference affects harvest acreage, income, and poverty. This effect can be inferred as a stochastic experiment in a lab and we establish random effect model which approaches regional specificity from a totally different angle compared to fixed effect model (10)-(12).

We follow Wooldridge (2002, p.286) in providing the following RE models under the assumption that the error component $\left(\epsilon_{i t}\right)$ is orthogonal to explanatory variables where $\epsilon_{i t}=\delta_{i}+v_{t}+e_{i t}$. $^{4}$

$$
\begin{aligned}
\ln y_{i t}-\vartheta_{i} \ln \overline{y_{l t}} & =\alpha\left(\ln v_{i t}-\vartheta_{i} \ln \overline{v_{l t}}\right)+\beta\left(\ln \varphi_{i t}-\vartheta_{i} \ln \overline{\varphi_{l t}}\right)+\gamma\left(\ln G i n i_{i t}-\right. \\
\vartheta_{i} \ln \overline{G_{l n l} l_{l t}} & +\left(\epsilon_{i t}-\vartheta_{i} \overline{\epsilon_{l t}}\right)
\end{aligned}
$$

$$
\begin{aligned}
& \operatorname{Gini}_{i t}-\vartheta_{i} \ln \overline{G l n l_{l t}}=\alpha\left(\ln v_{i t}-\vartheta_{i} \ln \overline{\mathrm{v}_{l t}}\right)+\beta\left(\ln \varphi_{i t}-\vartheta_{i} \ln \overline{\varphi_{l t}}\right)+\gamma\left(\ln y_{i t}-\right. \\
& \left.\vartheta_{i} \ln \overline{y_{l t}}\right)+\left(\epsilon_{i t}-\vartheta_{i} \overline{\epsilon_{l t}}\right) \\
& \ln \theta_{i t}-\vartheta_{i} \ln \overline{\theta_{l t}}=\alpha\left(\ln v_{i t}-\vartheta_{i} \ln \overline{v_{l t}}\right)+\beta\left(\ln \varphi_{i t}-\vartheta_{i} \ln \overline{\varphi_{l t}}\right)+\gamma\left(\ln y_{i t}-\vartheta_{i} \ln \overline{y_{l t}}\right)+ \\
& \zeta\left(\ln \operatorname{Gini}_{i t}-\vartheta_{i} \ln \overline{\operatorname{Gln}}_{i t}\right)+\left(\epsilon_{i t}-\vartheta_{i} \overline{\epsilon_{l t}}\right)
\end{aligned}
$$

To verify the assumption of $\operatorname{COV}\left(X_{i t}, \delta_{i}\right)=0$ and $\operatorname{COV}\left(X_{i t}, v_{t}\right)=0$ and to test whether the estimation is unbiased, the Hausman test is utilized. If the null hypothesis is rejected, it means that (10)-(12) and (13)-(15) are systematically different. 
The test result may also lead to an inference that there is spurious effect coming from regional specificity $\left(\delta_{i}\right)$ and that only FE estimators are consistent.

\section{Differnce in difference estimation}

For further studies, we measure the effect of soy introduction on poor regions by comparing them to regions that have no soybeans or to regions that already have soy. We estimate the effect of before-after soy introduction using difference-in-difference estimator which adjusts for initial differences by subtracting off each group's initial value of dependent variable as follows (Stock and Watson, 2003).

$$
\begin{gathered}
\hat{\beta}_{\text {diff-in-diff }}=\left(\bar{y}_{\text {introduction }, 2000}-\bar{y}_{\text {introduction }, 1991}\right)-\left(\bar{y}_{\text {control,2000 }}-\right. \\
\left.\bar{y}_{\text {control }, 1991}\right)
\end{gathered}
$$

An equation (17) is established to see the effect on poverty $\left(\ln \theta_{i t}\right)$, and it can be interpreted in two ways based on Assumptions 1 and 2 of the initial condition. Control variables $\left(X_{i t}\right.$, in logs) are included, as in (9), based on Hypotheses 1-3.

$$
\ln \theta_{i t}=\alpha+\beta Y e a r+\gamma D_{\text {intro }}+\delta \text { YearD } D_{\text {intro }}+\zeta^{\prime} X_{i t}+\epsilon_{i t}
$$

Assumption 1: $D_{\text {intro }}=0$ for regions that do not have soy in 1991 and 2000

Assumption 2: $D_{\text {intro }}=0$ for regions that have soy in 1991 and 2000 Where $D_{\text {intro }}=1$ for regions where there is no soy in 1991 but there is soy in 2000 and Year $=1$ for year 2000. The result of the estimation has the following meanings.

- $\alpha$ : initial poverty in 1991 for control group(no-soy/existing soy).

- $\alpha+\beta$ : poverty in 2000 for control group(no-soy/existing soy).

- $\alpha+\gamma:$ initial poverty in 1991 for soy-introducing area

- $\alpha+\beta+\gamma+\delta$ : poverty in 2000 for soy-introducing area 
Therefore, whether soy introduction influenced poverty during a decade is purely captured by $\delta$ based on the calculation following (18):

$$
\{(\alpha+\beta+\gamma+\delta)-(\alpha+\gamma)\}-\{(\alpha+\beta)-\alpha\}=\delta
$$

\section{Data}

The estimation is conducted in two steps. First we investigate national effect and northern versus southern regions utilizing panel data of fifteen administrative units (Estados), which have considerable soy acreage size, over a 38-year period of 19762013. We split the 15 administrative units into two groups of ten and five so as to compare between the northern and middle parts and the southern entities of Brazil. ${ }^{5}$

Second, we analyse five regions of the North, the Northeast, the Central west, the Southeast and the South using data at municipal level (municípios). The data for counties are decennial and we used the most recent data of 1991 and 2000. The number of municipalities fall under the above five regions is 5596, 1805, 468, 1672 and 1196 respectively.

Harvest area (Área colhida) of soy and other crops is from Municipal Agricultural Survey (Produção Agrícola Municipal,PAM) of Brazilian Institute of Geography and Statistics (Instituto Brasileiro de Geografia e Estatı'stica, IBGE). Regional per capita average monthly income, Gini index (at the level of administrative units), Theil index (at the municipal level) and the number of persons below poverty line $^{6}$ are from the National Survey by Household Sampling (Pesquisa Nacional por Amostra de Domicilios, PNAD) by IBGE. Regional per capita average income is deflated with prevailing prices in 2013. The PNAD survey is not conducted in 1980, 1991, 1994, 2000 and 2010, and unbalanced panel data is used. Most of data are 
retrieved from database of the Brazilian Institute for Economic Analysis (IPEA), a Brazilian government institution.

This paper uses comprehensive data of total poverty per region, not confined to the rural poor. Therefore, it should be noted that the result of the analysis shows the impact on the combination of rural and urban poor. Accordingly, if there is compensation for the aggravation of the rural poor by the form of the alleviation of the poor in non-agricultural sector, it would be reflected in the result.

\section{Results}

\section{Analysis at the national level}

Table 3 shows regression analysis for the effect of soy expansion on average income, Gini index, and the number of the poor at the national level. Results for fixed effect models (FE) are shown in Columns (1), (3) and (5), while Columns (2), (4) and (6) are for random effect models (RE) which are based on very different assumptions on the view of regional specificity. Hausman test result rejected the null hypothesis at $1 \%$ and we find that the coefficients of FE and RE are systematically different, which lead us to put greater faith in FE estimates.

We found a strong support for our hypotheses from the significant results. In Columns (1)-(6), all the soy coefficients are statistically significant, except in Column (1). In Columns (3)-(6), it is shown that an increase in soy acreage worsens inequality (0.00752 and 0.00676$)$ and poverty $(0.0514$ and 0.0528$)$ at $99 \%$ confidence level. The result illustrates that a one percent increment in the soy acreage raises the number of the poor by around 0.05 percent. 
The relation between soy and growth of average income is positive as many former studies have pointed out, but the standard error is found to be high in (1) and it may be partly due to some regions in which soy expansion did not lead to income growth.

Table 3. The impact of soy acreage expansion on growth-inequality-poverty at the national level

\begin{tabular}{|c|c|c|c|c|c|c|}
\hline \multirow{2}{*}{$\begin{array}{l}\text { Dependent } \\
\text { Var.: }\end{array}$} & \multicolumn{2}{|l|}{ Growth } & \multicolumn{2}{|l|}{ Gini } & \multicolumn{2}{|l|}{ Poverty } \\
\hline & (1) FE & (2) RE & (3) $\mathrm{FE}$ & (4) RE & (5) $\mathrm{FE}$ & (6) $R E$ \\
\hline \multirow[t]{2}{*}{ Constant } & $7.393^{\star \star \star}$ & $7.256^{\star \star \star}$ & $-1.224^{\star \star \star}$ & $-0.803^{\star \star \star}$ & $25.41^{\star \star \star}$ & $24.33^{\star \star \star}$ \\
\hline & $(0.335)$ & $(0.325)$ & $(0.164)$ & $(0.140)$ & $(0.712)$ & $(0.726)$ \\
\hline \multirow[t]{2}{*}{ soy } & 0.00576 & $0.00758^{*}$ & $0.00752^{\star \star \star}$ & $0.00676^{\star \star \star}$ & $0.0514^{\star \star \star}$ & 0.0528 *** \\
\hline & $(0.00415)$ & $(0.00419)$ & $(0.00140)$ & $(0.00141)$ & $(0.00591)$ & $(0.00621)$ \\
\hline \multirow[t]{2}{*}{ Other crops } & $-0.0710^{\star \star \star}$ & $-0.0667^{* \star *}$ & $0.0292^{\star \star \star}$ & 0.00978 & $0.0742^{\star *}$ & $0.119 * * *$ \\
\hline & $(0.0215)$ & $(0.0204)$ & (0.00745) & $(0.00610)$ & (0.0309) & (0.0310) \\
\hline \multirow[t]{2}{*}{ gini } & $0.246^{*}$ & 0.201 & & & 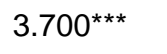 & $3.609 * \star *$ \\
\hline & $(0.144)$ & $(0.145)$ & & & $(0.205)$ & $(0.215)$ \\
\hline \multirow[t]{2}{*}{ growth } & & & $0.0300 *$ & 0.00832 & 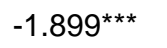 & $-1.848^{\star \star \star}$ \\
\hline & & & $(0.0175)$ & $(0.0157)$ & $(0.0716)$ & $(0.0736)$ \\
\hline Observations & 444 & & 444 & & 444 & \\
\hline Number of pid & 15 & & 15 & & 15 & \\
\hline R-squared & 0.821 & & 0.617 & & 0.898 & \\
\hline $\begin{array}{l}\text { Hausman's } \\
\text { Chi }\end{array}$ & $24.59 * * *$ & & $25.13 * * *$ & & $51.12 * * *$ & \\
\hline
\end{tabular}

Note: Standard errors in parentheses. Results for year dummies are omitted.

${ }^{\star * *} p<0.01,{ }^{* \star} p<0.05,{ }^{*} p<0.1$ 


\section{Results for the North versus South}

Table 4 presents the results of ten regions in the north versus five regions in the south. Hausman test result rejected the null hypothesis at $1 \%$ and we find that the coefficients of FE and RE are systematically different, which lead us to put greater faith in FE estimates.

In Column (1), we observe that when soy cultivation propagates by $1 \%$, the number of poor people increases by $0.05 \%$ in the north, where the large-scale acquisition of farmland is active, similar to the finding on the national average in Table 3. The soy coefficient $(0.0475)$ is statistically significant at $99 \%$ confidence level in FE analysis while the corresponding estimate is insignificant in (2).

The most distinguishable finding in the analysis is in (3)-(4). In southern Brazil, where family farming dominates, more soy acreage lowers the poverty by $0.04 \%$. This is in sharp contrast with the findings above. The soy coefficient is significant at $90 \%$ confidence level in FE and at 99\% confidence level in RE.

Table 4. The impact of soy acreage expansion on poverty in the north versus south Brazil

\begin{tabular}{lllll}
\hline \multirow{2}{*}{ VARIABLES } & \multicolumn{2}{c}{ North (poverty) } & \multicolumn{2}{c}{ South (poverty) } \\
\cline { 2 - 5 } & $(1) \mathrm{FE}$ & $(2) \mathrm{RE}$ & $(3) \mathrm{FE}$ & $(4) \mathrm{RE}$ \\
\hline Constant & $25.13^{\star \star \star}$ & $25.62^{\star \star \star}$ & $32.09^{\star \star \star}$ & $3.214^{\star \star \star}$ \\
& $(0.864)$ & $(1.460)$ & $(1.937)$ & $(1.086)$ \\
soy & $0.0475^{\star \star \star}$ & -0.0153 & $-0.0444^{\star}$ & $-0.269^{\star \star \star}$ \\
& $(0.00992)$ & $(0.0228)$ & $(0.0237)$ & $(0.0231)$ \\
Others & 0.0417 & $0.246^{\star \star \star}$ & -0.101 & $1.172^{\star \star \star}$ \\
& $(0.0407)$ & $(0.0529)$ & $(0.0961)$ & $(0.0774)$ \\
gini & $3.336^{\star \star \star}$ & $8.200^{\star \star \star}$ & $-2.129^{\star \star \star}$ & $4.869^{\star \star \star}$
\end{tabular}




\begin{tabular}{|c|c|c|c|c|}
\hline & $(0.261)$ & $(0.753)$ & $(0.108)$ & $(0.911)$ \\
\hline \multirow[t]{2}{*}{ growth } & $-1.895^{\star \star \star}$ & $-1.870^{\star \star \star}$ & $4.329^{\star \star \star}$ & -0.187 \\
\hline & $(0.0933)$ & (0.144) & $(0.390)$ & $(0.176)$ \\
\hline Observations & 279 & & 165 & \\
\hline Number of pid & 10 & & 5 & \\
\hline R-squared & 0.872 & & 0.973 & \\
\hline Hausman's Chi & $226.48^{\star \star \star}$ & & $111.63^{\star \star \star}$ & \\
\hline
\end{tabular}

Table 5 summarizes the elasticity of poverty with respect to soy acreage, which is from FE models that eliminated regional specificity by differencing. The statistically $1 \%$ significant result shows that the soy industry, at the countrywide level, significantly adds to the number of persons living below the poverty line. This result indicates that the negative impact of soy conglomerates is greater than its positive trickledown effect at nationwide.

Considering that soy acreage increased more than $150 \%$ during the period 1980 2010 in Brazil as shown in Figure 1, more than 7.7\% of the headcount of the poor has been added during thirty years because of soy expansion $(0.0514 \times 150)$. In similar calculation, in the North, soy farm has led to the increase of $7.1 \%$ of the number of the extreme poor in those years $(0.0475 \times 150)$.

However, in the South, an increase in soy acreage of one percent alleviates poverty. Therefore, from 1980 to 2010 , around $6.7 \%$ of the poor has escaped from poverty thanks to soybeans in the South $(-0.0444 \times 150)$. This contrasting finding indicates that the causal relationship between soy acreage and poverty stems from the different methods of soy farming. 
Table 5. Summary of the causal relationship between soy expansion and poverty

\begin{tabular}{|c|c|c|c|}
\hline & Nation-wide & The north & The south \\
\hline Soy $\rightarrow$ Poverty & $0.0514^{\star \star \star}$ & $0.0475^{\star \star \star}$ & $-0.0444^{*}$ \\
\hline
\end{tabular}

\section{Regional Comparison}

Table 6 illustrates the results for the north, the northeast and the central west, which is estimated at municipal level. The divide in the increasing impact on poverty between existing soy farms and newly introduced ones during the 1990s in the north is significant in our sample. Column (2) of Table 6 shows that soy introduction increased the number of poor people by $0.0286 \%$ in comparison to existing soy farms over ten years in the north. This is in contrast with other agricultural activities that decreased poverty $(-0.0196 \%)$. However, the soy introduction effect $\left(\right.$ Year $\left._{\text {intro }}\right)$ is not significant in other regions in (4) and (6).

The soy introduction effect on poverty compared to no-soy regions is found to be insignificant overall, as in (1), (3), and (5). $D_{\text {intro }}$ in (1) and (2) shows the divide in poverty in the initial period, which implies that new soy farms are likely to be located in poorer places than no-soy areas but less poor regions than pre-existing soy farms.

Table 6. Regression adjusted diff-in-diff. results, the northern region, 1991 and 2000

\begin{tabular}{ccccccc}
\hline $\begin{array}{c}\text { Dependent } \\
\text { Var.: }\end{array}$ & \multicolumn{2}{c}{ North } & \multicolumn{2}{c}{ Northeast } & \multicolumn{2}{c}{ Central west } \\
\cline { 2 - 6 } InPoverty & $\begin{array}{c}\text { (1)No soy- } \\
\text { Intro }\end{array}$ & (2)Soy-Intro & $\begin{array}{c}\text { (3)No soy- } \\
\text { Intro }\end{array}$ & $\begin{array}{c}\text { (4)Soy-Intro } \\
\text { Intro }\end{array}$ & $\begin{array}{c}\text { (5)No soy- } \\
\text { (6)Soy-Intro }\end{array}$ \\
\hline Intercept & $8.785^{\star \star \star}$ & $10.19^{\star \star \star}$ & $6.321^{\star \star \star}$ & $6.154^{\star \star \star}$ & $9.290^{\star \star \star}$ & $10.15^{\star \star \star}$ \\
year & $(0.0267)$ & $(0.0528)$ & $(0.0253)$ & $(0.111)$ & $(0.136)$ & $(0.113)$ \\
& -0.00640 & 0.00802 & $-0.0147^{\star \star \star}$ & -0.0321 & 0.0183 & 0.0121 \\
& $(0.00467)$ & $(0.00803)$ & $(0.00300)$ & $(0.0203)$ & $(0.0162)$ & $(0.0132)$
\end{tabular}




\begin{tabular}{|c|c|c|c|c|c|c|}
\hline \multirow[t]{2}{*}{$D_{\text {intro }}$} & $0.0258^{*}$ & $-0.0462^{\star \star \star}$ & -0.00253 & 0.0237 & -0.00717 & -0.0184 \\
\hline & (0.0146) & $(0.0136)$ & (0.0177) & (0.0187) & (0.0259) & $(0.0230)$ \\
\hline \multirow[t]{2}{*}{ YearD $D_{\text {intro }}$} & -0.0107 & $0.0286^{*}$ & 0.00877 & -0.00362 & -0.0277 & 0.00825 \\
\hline & $(0.0172)$ & (0.0161) & $(0.0239)$ & $(0.0247)$ & $(0.0324)$ & $(0.0283)$ \\
\hline \multirow[t]{2}{*}{ Growth } & $-0.910^{\star \star \star}$ & $-1.129 * \star \star$ & $-0.470^{\star \star \star}$ & $-0.387^{\star \star \star *}$ & $-1.031^{\star \star \star}$ & $-1.156^{\star \star \star}$ \\
\hline & (0.00389) & $(0.00912)$ & (0.00458) & $(0.0240)$ & $(0.0237)$ & $(0.0208)$ \\
\hline \multirow[t]{2}{*}{ Inequality } & 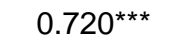 & $0.961 * \star \star$ & $0.162^{\star \star \star}$ & 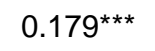 & $0.616^{\star \star \star}$ & $0.787^{* \star *}$ \\
\hline & $(0.0102)$ & (0.0154) & $(0.00692)$ & (0.0310) & $(0.0372)$ & $(0.0322)$ \\
\hline \multirow[t]{2}{*}{ Other crops } & $-0.00979 * \star \star$ & $-0.0196^{\star \star *}$ & $0.0117^{\star \star \star}$ & -0.00871 & 0.00727 & -0.00577 \\
\hline & (0.00173) & $(0.00354)$ & $(0.00121)$ & (0.00735) & $(0.00606)$ & (0.00485) \\
\hline Observations & 7,622 & 2,603 & 3,258 & 74 & 392 & 456 \\
\hline R-squared & 0.893 & 0.905 & 0.806 & 0.880 & 0.863 & 0.905 \\
\hline
\end{tabular}

Standard errors in parentheses

$* * * \mathrm{p}<0.01, * * \mathrm{p}<0.05,{ }^{*} \mathrm{p}<0.1$

Table 7 describes the results for the south and the southeast, which is analysed at municipal level. Column (2) shows that there is a significant alleviating impact of soy introduction on poverty compared to pre-existing soy farms in the South (-0.0442), which is in line with the findings for the north versus the south section.

However, in other regions, the soy introduction effect $\left(\right.$ Year $\left._{\text {intro }}\right)$ is insignificant. $D_{\text {intro }}=0.0566$ in Column (2) shows that new soy farms are introduced in poorer regions than traditional soy farms. The results for the year dummy in Column (2), (3) and (4) show that poverty has increased in the south and the southeast during the period due to causes other than soy.

Table 7. Regression adjusted diff-in-diff. results, the southern region, 1991 and 2000

Dependent Var.: South Southeast




\begin{tabular}{|c|c|c|c|c|}
\hline InPoverty & (1)No soy - Intro & (2) Soy-Intro & (3)No soy - Intro & (4)Soy-Intro \\
\hline \multirow[t]{2}{*}{ Intercept } & $11.81^{\star \star \star}$ & 10.09 *** & $10.02^{\star \star \star}$ & $12.22^{\star \star \star}$ \\
\hline & $(0.123)$ & (0.0778) & $(0.0430)$ & (0.110) \\
\hline \multirow[t]{2}{*}{ year } & 0.00633 & $0.0361^{\star \star *}$ & $0.0344^{\star \star \star}$ & $0.0994^{\star \star \star}$ \\
\hline & $(0.0154)$ & $(0.00924)$ & (0.00705) & $(0.0145)$ \\
\hline \multirow[t]{2}{*}{$D_{\text {intro }}$} & -0.0200 & $0.0566^{\star *}$ & 0.000491 & -0.0221 \\
\hline & (0.0295) & $(0.0224)$ & $(0.0200)$ & (0.0195) \\
\hline \multirow{2}{*}{ YearD $_{\text {intro }}$} & 0.0447 & $-0.0442^{\star}$ & -0.0404 & -0.0261 \\
\hline & $(0.0320)$ & $(0.0243)$ & $(0.0257)$ & $(0.0250)$ \\
\hline \multirow[t]{2}{*}{ Growth } & $-1.416^{* \star *}$ & $-1.178^{\star \star \star}$ & $-1.118^{\star \star *}$ & $-1.495^{\star \star \star}$ \\
\hline & (0.0188) & $(0.0120)$ & $(0.00728)$ & $(0.0219)$ \\
\hline \multirow[t]{2}{*}{ Inequality } & $1.099 * \star \star$ & $0.943^{\star * \star}$ & $0.886^{\star \star \star}$ & $1.071^{\star \star \star}$ \\
\hline & $(0.0259)$ & (0.0180) & $(0.0167)$ & $(0.0297)$ \\
\hline \multirow[t]{2}{*}{ Other crops } & $-0.0236^{\star * *}$ & $0.0182^{\star \star \star}$ & $-0.0160^{\star \star \star}$ & $-0.0227^{\star \star \star}$ \\
\hline & $(0.00568)$ & $(0.00484)$ & $(0.00237)$ & $(0.00667)$ \\
\hline Observations & 823 & 1,393 & 2,435 & 613 \\
\hline R-squared & 0.932 & 0.928 & 0.925 & 0.925 \\
\hline
\end{tabular}

Standard errors in parentheses

$* * * \mathrm{p}<0.01, * * \mathrm{p}<0.05, * \mathrm{p}<0.1$

Table 8 summarises the estimation at the municipal level, and the result backs the claim that soy/agribusiness aggravates poverty in the north, but family farming alleviates poverty in the south. However, the significant findings are based on the comparison of soy introduction versus pre-existing soy farms, and the results for soy introduction versus no soy are insignificant. This may be due to the diverse situations of no-soy areas, and different results could be drawn if no-soy regions were split into proper categories.

Table 8 . Summary of the soy introduction effect by region 


\begin{tabular}{cccccc}
\hline Soy $\rightarrow$ Poverty & $\begin{array}{c}\text { The } \\
\text { north }\end{array}$ & $\begin{array}{c}\text { The } \\
\text { northeast }\end{array}$ & $\begin{array}{c}\text { The central } \\
\text { west }\end{array}$ & $\begin{array}{c}\text { The } \\
\text { southeast }\end{array}$ & $\begin{array}{c}\text { The } \\
\text { south }\end{array}$ \\
\hline No soy vs. Introduction & -0.0107 & 0.00877 & -0.0277 & -0.0404 & 0.0447 \\
Soy vs. Introduction & $\mathbf{0 . 0 2 8 6 ^ { * }}$ & -0.00362 & 0.00825 & -0.0261 & $\mathbf{- 0 . 0 4 4 2 *}^{*}$ \\
\hline
\end{tabular}

$* * * \mathrm{p}<0.01, * * \mathrm{p}<0.05, * \mathrm{p}<0.1$

\section{Discussion}

It was found that the impact of soy on poverty in the north of the country, where land consolidation is active, is precisely opposite that of the south, where family farming dominates. In southern areas, the farming method is characterised by the mixed farming of staples mainly for home consumption. Moreover, the forest is a part of the farm, and there are more on-farm jobs compared to in the north. In contrast, the corporate farming in the northern region is characterised by mechanised monoculture plantations producing export products, and fewer labourers are hired.

The evidence from the panel data clearly shows that the different structure of the soy industry has different effects on poverty. We retrieved consistent estimates at the $1 \%$ significance level while controlling for the endogeneity problem owing to unobserved time-invariant regional specificity as well as time specific effects by establishing a twoway error component model. The result illustrates a significant causal relationship between the soy acreage and the rising number of the poor at the national average and in the northern region. After then, we also conducted regional analysis utilizing data at municipal level, of which result also supported the above claim. The empirical result describes that the benefits of trickledown effect, including the jobs created off-farm, do not outweigh the loss arising from the centralization of land plots. 
There is a stark contrast between the north and the south. In the south, where family farming dominates, larger soy farms only mean fewer poor people. It was found that what matters in the relationship between soy acreage and poverty is not the soy crop itself but the farming style.

Based on the findings of this study, family farming must be supported to help alleviate poverty. Government support is necessary so that this farming style can coexist with commercial farming. Recently, the Central Bank of Brazil (Banco Central do Brasil) started to support family farms via Programa National de Fortalecimento da Agricultura Familiar (PRONAF) to stimulate income generation and improve the use of family labour. In addition, the Government made it mandatory to purchase at least $30 \%$ of school meals from family farms (Vennet et al., 2015). This kind of support is more directed towards the rural poor, and it would be more sustainable and helpful for the disadvantaged than vocational training of farmers for off-farm jobs. For future studies, it is also necessary to conduct in-depth monitoring of the pro-poor effectiveness of PRONAF if it is to be adopted by other developing countries. 


\section{Note}

${ }^{1}$ The soy industry buys up small farmers' land and there is an argument that marginalized farmers then migrates into the Amazon region to deforest it. The government claims that soy farmers convert pasture, not primary forest, and they monitor whether the conversion complies with environmental policies. Steward (2007), however, reports that when colonos (tenant farmers) undertake logging activity in rain forests for settlement, soy farmers buy the colonos' land, and it is considered as non-forest land legally. Steward borrows the comment by Myers (1980) to describe this phenomenon, holding that it is "invasive forest mobility."

${ }^{2}$ Weinhold et al. (2013) concluded that the expansion of soybeans reduces absolute poverty because it raises median income. Nonetheless, the result should be interpreted that soy increases average income, not median income because this is based on incorrectly used data as they used the average income (Renda familiar - per capita - média) in IPEA which is not median (renda mediana) according to the author's email correspondence with Weinhold and Reis on March 25, 2014.

${ }^{3}$ EMBRAPA was established in 1976.

${ }^{4}(13)-(15)$ considers that $\left(\delta_{i}\right)$ random while still assuming that the time-specific effect $\left(v_{t}\right)$ is regarded as fixed effect.

5 Administrative units for each region are shown in Table 1. 
${ }^{6}$ IPEA provides two different types of data for the number of persons living below the poverty line. One is a poverty line established by UNDP, which is a half of the minimum wage set by UNDP and the other is the country's definition of the poverty line (The poverty line here is a value of a basket of food with minimum calories based on recommendations of FAO and WHO), which is more conservative term than UNDP. We used extreme poverty data set by IPEA. 


\section{References}

Aguiar, et al. 2013. Pervasive transition of the Brazilian land-use system. Nature Climate Change 4, no. 1:27-35. doi:10.1038/nclimate2056

Arima, Eugenio Y, Peter Richards, Robert Walker, and Marcellus M Caldas. 2011. "Statistical confirmation of indirect land use change in the Brazilian Amazon." Environmental Research Letters 6 (2):024010.

Baletti, Brenda. 2012. "Ordenamento Territorial: Neo-developmentalism and the struggle for territory in the lower Brazilian Amazon." The Journal of Peasant Studies 39 (2):573-598.

Banco Central do Brasil. http://www.bcb.gov.br/?PRONAFFAQ

Baumgartner, P., von Braun, J., Abebaw, D., \& Müller, M. 2015. Impacts of Largescale Land Investments on Income, Prices, and Employment: Empirical Analyses in Ethiopia. World Development, 72(0), 175-190. doi: http://dx.doi.org/10.1016/j.worlddev.2015.02.017

Borras, J. R., \& Franco, J. C. 2012. Global land grabbing and trajectories of agrarian change: A preliminary analysis. Journal of Agrarian Change, 12(1), 34-59.

Bourguignon, F. 2003. "The Growth Elasticity of Poverty Reduction: Explaining Heterogeneity across Countries and Time-periods," in T. Eichler and S. Turnovsky (eds.), Growth and Inequality, Cambridge, Mass.: MIT Press.

Bues, A. 2011. Agricultural foreign direct investment and water rights: An institutional analysis from Ethiopia. In M. Tadesse, B. Alemu, G. Bekele, T. Tebikew, J. Chamberlin, \& T. Benson (Eds.), Atlas of the Rural Ethiopian Economy 2006. Addis Ababa: IFPRI/CSA/ERDI.

von Braun, J., \& Meinzen-Dick, R. 2009. "Land Grabbing” by foreign investors in developing countries: Risks and opportunities. IFPRI Policy Brief, 13(April).

Coelho, Marcos de Amorim. 1998. Geografia do Brasil. Editora Moderna, São Paulo.

Cotula, L., Vermeulen, S., Leonard, R., \& Keeley, J. 2009. Land grab or development opportunity? Agricultural investment and international land deals in Africa. London/Rome: IIED/FAO/IFAD, p. 130.

Datt, G., \& Ravallion, M. (1992). Growth and redistribution components of changes in poverty measures: A decomposition with applications to Brazil and India in the 1980s. Journal of development economics, 38(2), 275-295. 
Deininger, K., Byerlee, D., Lindsay, J., Norton, A., Selod, H., \& Stickler, M. 2010. Rising global interest in Farmland - Can it yield sustainable and equitable benefits?. Washington, DC: World Bank.

De Schutter, Olivier. 2011. "How not to think of land-grabbing: three critiques of largescale investments in farmland." The Journal of Peasant Studies 38 (2):249-279.

Djiré, M. 2007. Land registration in Mali - No land ownership for farmers? Issue paper 144, Drylands Programme, IIED. London.

Evers, S., Burnod, P., Ratsialonana, R. A., \& Teyssier, A. (2011). Foreign land acquisitions in madagascar: competing jurisdictions of access claims. African engagements: Africa negotiating an emerging multipolar world. Brill, Leyde, 110-132.

Ferreira, J., R. Pardini, J.P. Metzger, C.R. Fonseca, P.S. Pompeu, G. Sparovek, and J. Louzada. 2012. Towards environmentally sustainable agriculture in Brazil: Challenges and opportunities for applied ecological research. Journal of Applied Ecology 49: 535-541.

Franco, J. 2008. Making land rights accessible: social movement innovation and political-legal strategies in the Philippines Journal of development studies, 44(7): 991-221.

Garrett, Rachael D., and Lisa L. Rausch. 2015. "Green for gold: social and ecological tradeoffs influencing the sustainability of the Brazilian soy industry." The Journal of Peasant Studies:1-33.

Grewal, B., Grunfeld, H., \& Sheehan, P. 2012. The contribution of agricultural growth to poverty reduction. Australian Centre for International Agricultural Research (ACIAR).

Gudynas, Eduardo. 2008. "The New Bonfire of Vanities: soybean cultivation and globalization in South America." Development 51 (4):512-518.

Hecht, Susanna B, and Charles Mann. 2008. "How Brazil outfarmed the American farmer." Fortune 157:92-105.

Heredia, Beatriz, Moacir Palmeira, and Sérgio Pereira Leite. 2010. "Sociedade e economia do "agronegócio" no Brasil." Revista Brasileira de Ciências Sociais 25 (74):159-176. 
HLPE. 2011. Land tenure and international investments in agriculture. A report by the high level panel of experts (HLPE) on food security and nutrition. Rome: Committee on World Food Security.

IBGE. www.sidra.ibge.gov.br

Instituto Nacional de Pesquisas Espaciais (INPE). 2014. Projecto PRODES.

IPEADATA. http://www.ipeadata.gov.br/

Jain, L. R., \& Tendulkar, S. D. (1990). Role of growth and distribution in the observed change in headcount ratio measure of poverty: a decomposition exercise for India. Indian Economic Review, 165-205.

Kakwani, N. 1993. Poverty and economic growth with application to cote d'ivoire. Review of Income and Wealth 39, no 2: 121-39.

Lima, M., Skutsch, M., \& de Medeiros Costa, G. 2011. Deforestation and the social impacts of soy for biodiesel: perspectives of farmers in the South Brazilian Amazon. Ecology and Society, 16(4), 4.

Martinelli, L. A., Naylor, R., Vitousek, P. M., \& Moutinho, P. 2010. Agriculture in Brazil: impacts, costs, and opportunities for a sustainable future. Current Opinion in Environmental Sustainability, 2(5), 431-438.

Morton, Douglas C, Ruth S DeFries, Yosio E Shimabukuro, Liana O Anderson, Egidio Arai, Fernando del Bon Espirito-Santo, Ramon Freitas, and Jeff Morisette. 2006. "Cropland expansion changes deforestation dynamics in the southern Brazilian Amazon." $\quad$ Proceedings of the National Academy of Sciences 103 (39):1463714641.

Noronha, S., Ortiz, L., \& Schlesinger, S. 2006. Agronegócio e biocombustíveis: uma mistura explosiva-impactos da expansão das monoculturas para a produção de bioenergia. Rio de Janeiro: Núcleo Amigos da Terra/Brasil.

PNAD.

ftp://ftp.ibge.gov.br/Trabalho_e_Rendimento/Pesquisa_Nacional_por_Amostra_ de_Domicilios_anual/

Produção Agrícola Municipal ftp://ftp.ibge.gov.br/Producao_Agricola/Producao_Agricola_Municipal_\%5Ban ual $\% 5 \mathrm{D}$ 
Ravallion, Martin, and Monika Huppi. 1991. "Measuring changes in poverty: a methodological case study of Indonesia during an adjustment period." The World Bank Economic Review 5 (1):57-82.

Ribeiro, M.C., J.P. Metzger, A.C. Martensen, F.J. Ponzoni, and M.M. Hirota. 2009. The Brazilian

Atlantic Forest: How much is left, and how is the remaining forest distributed? Implications for conservation. Biological Conservation 142, no. 6: 1141-1153.

Sauer, Sérgio, and Sergio Pereira Leite. 2012. "Agrarian structure, foreign investment in land, and land prices in Brazil." Journal of Peasant Studies 39 (3-4):873-898.

Smaller, C., \& Mann, H. 2009. A Thirst for Distant Lands: Foreign investment in agricultural land and water. Winnipeg, Manitoba: International Institute for Sustainable Development (IISD).

Steward, C. 2007. From colonization to "environmental soy": A case study of environmental and socio-economic valuation in the Amazon soy frontier. Agriculture and Human Values, 24, 107-122.

Stock, J. H., \& Watson, M. W. (2003). Introduction to econometrics (Vol. 104): Addison Wesley Boston.

Vander Vennet, Bert, Sergio Schneider, and Joost Dessein. 2015. "Different farming styles behind the homogenous soy production in southern Brazil." The Journal of Peasant Studies (ahead-of-print):1-23.

Weinhold, Diana, Killick, Evan \& Reis, Eustáquio J. 2013. Soybeans, poverty and inequality in the Brazilian Amazon. World Development

WESZ Jr., V. J. (2008), Características e dinâmicas das agroindústrias esmagadoras de soja no Brasil: uma leitura preliminar. Rio de Janeiro, CPDA/UFRRJ, PPGAS/MN/UFRJ, PPGSA/IFCS/UFRJ (Pesquisa Sociedade e Economia doAgronegócio, mimeo.).

Wooldridge, J.M. 2010. Econometric analyis of cross section and panel data.De Schutter, Olivier. 2011. "How not to think of land-grabbing: three critiques of large-scale investments in farmland." The Journal of Peasant Studies 38 (2):249-279.

Zoomers, Annelies. 2010. "Globalisation and the foreignisation of space: seven processes driving the current global land grab." The Journal of Peasant Studies 37 (2):429-447. 